\title{
Effect of Fly Ash Based Organic Application on Plant Biomass and Bio Concentration of Major and Micro Nutrients in Nursery Seedlings of Simarouba gluca
}

\author{
L. Rajashekhar*, N.A. Yeledhalli and S.J. Patil \\ Department of Soil Science and Agricultural Chemistry, University of Agricultural Sciences, \\ Dharwad -58005, Karnataka, India \\ *Corresponding author
}

\begin{tabular}{|c|c|}
\hline & A B S T R A C T \\
\hline & \multirow{6}{*}{$\begin{array}{l}\text { Fly ash was mixed with FYM, Vermicompst and soil in different ratios on a w/w was used } \\
\text { for growing nursery seedlings of Simarouba gluca with object of response of pot mixture } \\
\text { on biomass production and bioconcentration } \mathrm{N}, \mathrm{P}, \mathrm{K}, \mathrm{S} \text { and } \mathrm{Zn}, \mathrm{Fe}, \mathrm{Cu} \text { and } \mathrm{Mn} \text { in stems } \\
\text { and leaves. Fly ash based organic substrate application of } \mathrm{FA}+\mathrm{FYM} / \mathrm{VC} \text { in } 1: 3 \text { ratio (w/w) } \\
\text { followed by } 1: 2 \text { ratio. Was found to be optimum for preparing potting mix for Simarouba } \\
\text { gluca Biomass accumulation in the stems and roots increased with increase in the ratio of } \\
\text { fly ash to FYM/VC application. Up to } 1: 3 \text { ratio. Whereas the biomass accumulation in } \\
\text { leaves as well as total biomass accumulation in the Simarouba saplings. Bioconcentratio } \\
\text { concentration } \mathrm{N}, \mathrm{P}, \mathrm{K}, \mathrm{S} \text { and micronutrients } \mathrm{Zn}, \mathrm{Fe}, \mathrm{Cu}, \mathrm{Mn} \text { and in stem and leaves of } \\
\text { Simarouba gluca displayed higher values in all the pot mixture treatment combinations. } \\
\text { However, Variations in the concentration of nutrient elements in the plants and uptake by } \\
\text { the leaves and stem of nursery seedling of Simarouba gluca was observed for major N.P.K } \\
\text { nutrients which varied as } \mathrm{N}=\mathrm{K}>\mathrm{P} \text {, secondary nutrients varied as } \mathrm{Ca}>\mathrm{S}>\mathrm{Mg} \text { and micro } \\
\text { nutrients varied as Fe }>\mathrm{Mn}>\mathrm{Zn}>\mathrm{Cu} \text {. The study indicates that the Simarouba gluca had high } \\
\text { potential for nutrient uptake due to high biomass production during seedling growth } \\
\text { besides fast growth. Fly ash based organic substrates pot mixtures when added to the soil } \\
\text { in different ratios benefits biomass production and increase in plant growth which in turn } \\
\text { attains significance from the point of view of eco-friendly disposal of fly ash. }\end{array}$} \\
\hline Keywords & \\
\hline $\begin{array}{l}\text { Fly ash, FYM, } \\
\text { Vermicompost, } \\
\text { Bioconcentratio } \\
\text { Biomass } \\
\text { accumulation an } \\
\text { nutrient uptake. }\end{array}$ & \\
\hline Articl & \\
\hline & \\
\hline & \\
\hline
\end{tabular}

\section{Introduction}

Fly ash is a repository of nutrients which can benefit plant growth and increase biomass production. Fly ash has been reported to contain low amounts of $\mathrm{C}$ and $\mathrm{N}$, medium amounts of available $\mathrm{K}$ and high concentration of available $\mathrm{P}$ (Sharma and Kalra, 2006). Species belonging to Simarouba (Simarouba gluca) is an ecofriendly tree with well-developed root system and with evergreen dense canopy efficiently checks soil erosion, recharges ground water supports soil microbial life, and improves soil fertility. The addition of biomass to waste land @ 1015 tonnes/ha/year helps in the improvement of soil fertility. Plant species achieve a chemical equilibrium with respect to a particular medium or pot mixture exposure (Mountouris et al., 2002). Distribution of any element in environment is dependent on continuous exchange between air, water, soil/sediment and biota (Agoramoorthy et al., 2008). In the present study, fly ash was used 
as a soil amendment along with FYM, VC with and without soil for nursery seedlings of Simarouba gluca. To know its response on biomass production and uptake of major and micro nutrients in the stems and leaves.

\section{Materials and methods}

Fly ash was collected West Coast Paper Mills Dandeli, Karnataka state. India was air-dried prior to analysis. Soil for the experiment was collected from Agro forestry division, MARS, Dharwad.0-30 cm depth and spread on polythene sheets, air-dried and sieved through a $2 \mathrm{~mm}$ sieve for chemical analysis. The $\mathrm{pH}$ of fly ash and soil used in the study was 6.97 and 7.41 and electrical conductivity was 0.20 and $0.40\left(\mathrm{dSm}^{-1}\right)$ respectively. The chemical properties of fly ash and soil used in the study are presented in the Table 1. Pot mixtures were prepared with fly ash, FYM, VC and soil. With fly ash was mixed with FYM, VC and soil on w/w basis in different proportions. $\mathrm{FA}+\mathrm{FYM}$ and FA+VC in $1: 1,1: 1,1: 2,1: 3$, $0: 1,2: 1,3: 1$ ratios and FA+FYM+SOIL and FA+VC +SOIL in 1:0:1, 1:1:1, 1:2:1, 1:3:1, $0: 1: 1,2: 1: 1,3: 1: 1$ ratios as per treatment details. The physico-chemical properties are presented Table 2. The different fly ash-soil mixtures were placed in polythene bags perforated at the bottom. Shoot cuttings for the nursery trial were taken from full grown trees of Simarouba gluca. The bags were placed in a nursery watering and weeding was carried out regularly. The nursery was grown over a period 150 days. After 150 days the reprsentive plants Simarouba gluca were gently uprooted and washed with water to remove any adhering soil particles. Thereafter the plants were dried with blotting sheets and weighed for fresh weight. The plants were then kept overnight in an oven at $65^{\circ} \mathrm{C}$ and weighed again for dry weight. To measure the bioconcentration major and micro nutrients in stems and leaves, the dried leaves and stems were ground followed by sieving with a 0.2 $\mathrm{mm}$ sieve to obtain a fine powder and analyzed for $\mathrm{N}, \mathrm{P}, \mathrm{K}, \mathrm{S}$ and $\mathrm{Zn}, \mathrm{Fe}, \mathrm{Cu}, \mathrm{Mn}$ and uptake was calculated.

\section{Results and Discussion}

\section{Dry biomass production}

\section{Without soil}

The dry bio mass of Simarouba gluca (3.12 g plant $^{-1}$ ) recorded in treatment $\mathrm{T} 8$ containing 1:1:1 was $3.12 \mathrm{~g} \mathrm{plant}^{-1}$ which increased significantly to $6.71 \mathrm{~g} \mathrm{plant}^{-1}$ in the treatment T4 with pot mixture FA+FYM. in 1:3:1 ratio The dry biomass of Simarouba was $3.21 \mathrm{~g}$ plant $^{-1}$ in treatment T8 containing $\mathrm{FA}+\mathrm{FYM} / \mathrm{VC}+\mathrm{SOIL}$ in $(1: 1: 1)$ ratio which increased to $7.15 \mathrm{~g}$ plant $^{-1}$ in the treatment $\mathrm{T}_{4}$ pot mixture containing $\mathrm{FA}+\mathrm{VC}$. In general higher dry biomass (shoot + leaf) was recorded in the treatments containing $\mathrm{FA}+\mathrm{VC}$ as compared to pot mixture containing FA + FYM (Table 2).

\section{With soil}

It was observed that the dry biomass of nursery seedling was positively influenced due to treatment effect. The dry biomass in control treatment $\mathrm{T}_{8}-\mathrm{C} 1$ was $3.21 \mathrm{~g} \mathrm{plant}^{-1}$ which significantly increased to $8.87 \mathrm{~g} \mathrm{plant}^{-1}$ due to treatment $\mathrm{T}_{4}$ pot mixture containing $\mathrm{FA}+\mathrm{VC}+\mathrm{SOIL}$ in 1:3:1 ratio.

Marcer et al., (1995) observed that increase in the number of branches and leaves of Simarouba gluca due to pot mixtures containing fly ash and sewage sludge. The biomass production of nursery seedling of Simarouba gluca was generally higher in pot mixtures containing fly ash and organic substrates. The reasons may be attributed to improved available nutrient in the pot mixtures (Pryor, 1976). Incorporation of fly ash as a pot mixture with organic substrates 
and soil had significant effect as compared to the control. Improved seedling growth and biomass production would depend on the uptake of nutrients by the plants (Cavaleri et al., 2004).

\section{Major nutrients (N, P, K)}

The data presented in Table 3 indicates that the uptake of nutrient elements was measured generally in the order $\mathrm{K}=\mathrm{N}>\mathrm{P}$. The maximum uptake of major nutrients was recorded in treatment $\mathrm{T}_{4}(1: 3)$ containing either fly ash, FYM and vermicompost.

However, the treatment $T_{2}$ and $T_{3}$, receiving fly ash, FYM in (1:1) and (1:2) ratios were on par with each other. The treatment receiving only fly ash in the pot mixture showed the lowest N, P and K uptake by the plant

Table.1 Initial physico-chemical properties of soil, fly ash, vermicompost and farmyard manure used for pot mixture

\begin{tabular}{|c|c|c|c|c|c|}
\hline $\begin{array}{l}\text { Sl. } \\
\text { No. }\end{array}$ & Properties & Soil & Fly ash & Vermicompost & $\begin{array}{c}\text { Farmyard } \\
\text { Manure }\end{array}$ \\
\hline \multicolumn{6}{|c|}{ Physical } \\
\hline 1 & $\begin{array}{c}\text { Particle } \\
\text { Sand }(\%) \\
\text { Silt }(\%) \\
\text { Clay }(\%) \\
\end{array}$ & $\begin{array}{l}65.0 \\
15.1 \\
20.2\end{array}$ & $\begin{array}{l}36.50 \\
47.40 \\
16.10\end{array}$ & $\begin{array}{l}- \\
- \\
-\end{array}$ & $\begin{array}{l}- \\
- \\
-\end{array}$ \\
\hline 2 & Texture & $\begin{array}{c}\text { Sandy clay } \\
\text { loam }\end{array}$ & Silty loam & - & - \\
\hline 3 & Bulk density $\left(\mathrm{Mg} \mathrm{m}^{-3}\right)$ & 1.40 & 0.98 & 0.43 & 0.41 \\
\hline 4 & Water holding capacity $(\%)$ & 14.00 & 28.90 & 65.9 & 58.35 \\
\hline \multicolumn{6}{|c|}{ Chemical } \\
\hline 5 & Reaction(pH) & 7.41 & 6.97 & 7.20 & 7.60 \\
\hline 6 & Electrical Conductivity $\left(\mathrm{dSm}^{-1}\right)$ & 0.20 & 0.40 & 0.82 & 0.65 \\
\hline 7 & Organic carbon $\left(\mathrm{g} \mathrm{kg}^{-1}\right)$ & 8.30 & 1.20 & 14.21 & 12.31 \\
\hline 8 & Total N (\%) & - & 0.39 & 1.21 & 0.50 \\
\hline 9 & Total P $(\%)$ & - & 0.10 & 0.86 & 0.26 \\
\hline 10 & Total K (\%) & - & 0.94 & 1.01 & 0.55 \\
\hline 11 & Total S (\%) & - & 0.77 & 0.37 & 0.28 \\
\hline 12 & Total Ca $(\%)$ & - & 1.12 & 1.32 & 1.50 \\
\hline 13 & Total Mg (\%) & - & 0.18 & 0.94 & 0.98 \\
\hline 14 & Zinc (\%) & - & 0.16 & 0.40 & 0.33 \\
\hline 15 & Copper (\%) & - & 0.13 & 0.32 & 0.30 \\
\hline 16 & Iron $(\%)$ & - & 1.27 & 1.63 & 1.55 \\
\hline 17 & Manganese (\%) & - & 1.31 & 1.09 & 0.40 \\
\hline 18 & Available $\mathrm{N}\left(\mathrm{kg} \mathrm{ha}^{-1}\right)$ & 204.34 & - & - & - \\
\hline 19 & Available $\mathrm{P}\left(\mathrm{kg} \mathrm{ha}^{-1}\right)$ & 20.36 & - & - & - \\
\hline 20 & Available $\mathrm{K}\left(\mathrm{kg} \mathrm{ha}^{-1}\right)$ & 220.07 & - & - & - \\
\hline 21 & Zinc $\left(\mathrm{mg} \mathrm{kg}^{-1}\right)$ & 0.94 & - & - & - \\
\hline 22 & Copper $\left(\mathrm{mg} \mathrm{kg}^{-1}\right)$ & 1.80 & - & - & - \\
\hline 23 & Iron $\left(\mathrm{mg} \mathrm{kg}^{-1}\right)$ & 6.02 & - & - & - \\
\hline 24 & Manganese $\left(\mathrm{mg} \mathrm{kg}^{-1}\right)$ & 11.21 & - & - & - \\
\hline
\end{tabular}


Table.2 Effect of Fly ash, FYM and VC pot mixtures on dry biomass (g plant ${ }^{-1}$ ) of Simarouba gluca

\begin{tabular}{|c|c|c|c|c|c|c|c|c|c|c|c|}
\hline \multirow{3}{*}{ Treatments } & \multicolumn{5}{|c|}{ Shoot+Leaf biomass $\left(\right.$ g plant $\left.^{-1}\right)$} & \multicolumn{6}{|c|}{ Root biomass (g plant ${ }^{-1}$ ) } \\
\hline & \multicolumn{2}{|c|}{ Without soil } & & \multicolumn{2}{|c|}{ With soil } & \multirow[b]{2}{*}{ Treatments } & \multicolumn{2}{|c|}{ Without soil } & \multirow[b]{2}{*}{$\begin{array}{l}\text { Treatments } \\
\text { With soil }\end{array}$} & \multicolumn{2}{|c|}{ With soil } \\
\hline & $\mathrm{FA}+\mathrm{FYM}$ & $\mathrm{FA}+\mathrm{VC}$ & $\begin{array}{l}\text { Treatments } \\
\text { With soil }\end{array}$ & $\begin{array}{c}\text { FA+FYM } \\
+ \text { SOIL }\end{array}$ & $\begin{array}{c}\mathrm{FA}+\mathrm{VC} \\
+\mathrm{SOIL}\end{array}$ & & $\mathrm{FA}+\mathrm{FYM}$ & $\mathrm{FA}+\mathrm{VC}$ & & $\begin{array}{c}\text { FA+FYM } \\
+ \text { SOIL }\end{array}$ & $\begin{array}{c}\text { FA+VC } \\
+ \text { SOIL }\end{array}$ \\
\hline T1(1:0) & 4.27 & 4.87 & T1(1:0:1) & 5.48 & 5.66 & $\mathrm{~T} 1(1: 0)$ & 1.28 & 2.86 & T1(1:0:1) & 2.67 & 3.41 \\
\hline T2(1:1) & 6.02 & 6.90 & $\mathrm{~T} 2(1: 1: 1)$ & 7.04 & 7.73 & $\mathrm{~T} 2(1: 1)$ & 1.37 & 3.03 & $\mathrm{~T} 2(1: 1: 1)$ & 3.50 & 4.16 \\
\hline T3(1:2) & 6.58 & 7.04 & $\mathrm{~T} 3(1: 2: 1)$ & 7.29 & 7.57 & $\mathrm{~T} 3(1: 2)$ & 1.96 & 3.44 & $\mathrm{~T} 3(1: 2: 1)$ & 4.57 & 4.73 \\
\hline T4(1:3) & 6.71 & 7.15 & $\mathrm{~T} 4(1: 3: 1)$ & 7.57 & 8.87 & $\mathrm{~T} 4(1: 3)$ & 2.29 & 3.55 & T4(1:3:1) & 5.03 & 5.15 \\
\hline T5(0:1) & 6.01 & 6.34 & T5(0:1:1) & 7.34 & 8.44 & T5(0:1) & 2.50 & 2.81 & T5(0:1:1) & 4.34 & 4.27 \\
\hline T6(2:1) & 4.61 & 5.70 & T6(2:1:1) & 6.58 & 7.80 & T6(2:1) & 4.36 & 2.53 & T6(2:1:1) & 3.35 & 4.19 \\
\hline T7(3:1) & 3.85 & 4.32 & T7(3:1:1) & 5.72 & 6.88 & $\mathrm{~T} 7(3: 1)$ & 3.86 & 2.27 & T7(3:1:1) & 3.15 & 3.67 \\
\hline T8 C1 (1:1:1) & 3.12 & 3.12 & T8 C1 $(1: 1: 1)$ & 3.12 & 3.12 & T8 C1(1:1:1) & 3.31 & 3.31 & T8 C1 $(1: 1: 1)$ & 3.31 & 3.31 \\
\hline T9 C2(1:1:1) & 5.69 & 5.69 & T9 C2(1:1:1) & 5.69 & 5.69 & T9 C2(1:1:1) & 2.32 & 2.32 & T9 C2(1:1:1) & 2.32 & 2.32 \\
\hline MEAN & 5.32 & 5.79 & MEAN & 6.32 & 6.86 & MEAN & 2.58 & 2.90 & MEAN & 3.58 & 3.91 \\
\hline SEm \pm & 0.073 & 0.074 & SEm \pm & 0.07 & 0.11 & SEm \pm & 0.07 & 0.084 & SEm \pm & 0.079 & 0.087 \\
\hline $\mathrm{CD}(\mathrm{P}=\mathbf{0 . 0 1})$ & 0.292 & 0.294 & $\mathrm{CD}(\mathrm{P}=0.01)$ & 0.30 & 0.44 & $\begin{array}{c}\mathrm{CD} \\
(\mathrm{P}=0.01)\end{array}$ & 0.26 & 0.334 & $\mathrm{CD}(\mathrm{P}=0.01)$ & 0.313 & 0.349 \\
\hline
\end{tabular}

Table.3 Effect of Fly ash, FYM, and VC pot mixtures on plant uptake of major nutrients $\left(\mathrm{mg} \mathrm{plant}^{-1}\right.$ ) by Simarouba gluca

\begin{tabular}{|c|c|c|c|c|c|c|c|c|c|c|c|c|c|}
\hline \multirow{2}{*}{$\begin{array}{l}\text { Treatments } \\
\text { without soil }\end{array}$} & \multicolumn{3}{|c|}{ FA+FYM } & \multicolumn{3}{|c|}{$\mathrm{FA}+\mathrm{VC}$} & \multirow{2}{*}{$\begin{array}{c}\text { Treatments } \\
\text { with soil }\end{array}$} & \multicolumn{3}{|c|}{ FA+FYM+SOIL } & \multicolumn{3}{|c|}{$\mathrm{FA}+\mathrm{VC}+\mathrm{SOIL}$} \\
\hline & $\mathbf{N}$ & $\mathbf{P}$ & $\mathbf{K}$ & $\mathbf{N}$ & $\mathbf{P}$ & $\mathbf{K}$ & & $\mathbf{N}$ & $\mathbf{P}$ & $\mathbf{K}$ & $\mathbf{N}$ & $\mathbf{P}$ & $\mathbf{K}$ \\
\hline $\mathrm{T} 1(1: 0)$ & 23.91 & 5.12 & 29.89 & 25.32 & 5.84 & 26.30 & $\mathrm{~T} 1(1: 0: 1)$ & 35.62 & 8.77 & 46.03 & 33.96 & 8.49 & 44.15 \\
\hline $\mathrm{T} 2(1: 1)$ & 46.96 & 10.84 & 51.17 & 59.34 & 13.11 & 58.65 & $\mathrm{~T} 2(1: 1: 1)$ & 57.73 & 14.08 & 68.99 & 69.57 & 17.01 & 70.34 \\
\hline T3(1:2) & 57.90 & 12.86 & 63.17 & 66.18 & 15.49 & 66.18 & T3(1:2:1) & 69.98 & 14.58 & 69.98 & 72.67 & 18.17 & 70.40 \\
\hline $\mathrm{T} 4(1: 3)$ & 64.17 & 16.96 & 84.81 & 69.99 & 19.56 & 90.47 & $\mathrm{~T} 4(1: 3: 1)$ & 76.70 & 18.85 & 86.84 & 79.21 & 23.06 & 88.70 \\
\hline T5(0:1) & 36.92 & 10.82 & 37.26 & 41.21 & 11.41 & 35.93 & $\mathrm{~T} 5(0: 1: 1)$ & 51.38 & 14.68 & 46.24 & 59.92 & 16.88 & 54.86 \\
\hline T6(2:1) & 36.42 & 9.22 & 38.19 & 52.78 & 11.40 & 52.44 & T6(2:1:1) & 57.38 & 13.16 & 61.85 & 75.73 & 15.17 & 74.88 \\
\hline $\mathrm{T} 7(3: 1)$ & 27.72 & 6.93 & 33.88 & 44.96 & 7.69 & 42.34 & $\mathrm{~T} 7(3: 1: 1)$ & 51.09 & 8.84 & 55.92 & 74.87 & 12.38 & 82.15 \\
\hline T8 C1(1:1:1) & 24.65 & 4.99 & 22.46 & 25.58 & 4.99 & 22.46 & T8 C1(1:1:1) & 24.96 & 4.99 & 22.46 & 24.96 & 4.85 & 22.46 \\
\hline T9 C2(1:1:1) & 47.23 & 10.24 & 39.83 & 50.07 & 10.24 & 39.83 & T9 C2(1:1:1) & 47.23 & 10.24 & 39.83 & 47.23 & 10.24 & 39.83 \\
\hline MEAN & 44.32 & 9.78 & 44.52 & 51.38 & 11.08 & 48.29 & MEAN & 56.12 & 12.02 & 57.13 & 63.01 & 14.03 & 60.86 \\
\hline SEm \pm & 0.11 & 0.10 & 0.33 & 0.16 & 0.16 & 0.28 & SEm \pm & 0.22 & 0.10 & 0.29 & 0.36 & 0.15 & 0.14 \\
\hline $\mathrm{CD}(\mathrm{P}=0.01)$ & 0.45 & 0.40 & 1.32 & 0.62 & 0.63 & 1.12 & $\mathrm{CD}(\mathrm{P}=0.01)$ & 0.87 & 0.42 & 1.17 & 1.43 & 0.60 & 0.55 \\
\hline
\end{tabular}




\section{Int.J.Curr.Microbiol.App.Sci (2017) 6(10): 3366-3372}

Table.4 Effect of Fly ash, FYM, and VC pot mixtures on plant uptake micronutrient (mg plant ${ }^{-1}$ ) Simarouba gluca

\begin{tabular}{|c|c|c|c|c|c|c|c|c|c|c|c|c|c|c|c|c|c|}
\hline \multirow{2}{*}{$\begin{array}{l}\text { Treatments } \\
\text { without soil }\end{array}$} & \multicolumn{4}{|c|}{ FA+FYM } & \multicolumn{4}{|c|}{$\mathrm{FA}+\mathrm{VC}$} & \multirow{2}{*}{$\begin{array}{l}\text { Treatments } \\
\text { with soil }\end{array}$} & \multicolumn{4}{|c|}{ FA+FYM+SOIL } & \multicolumn{4}{|c|}{ FA+VC+SOIL } \\
\hline & $\mathbf{Z n}$ & $\mathbf{C u}$ & $\mathbf{F e}$ & Mn & $\mathbf{Z n}$ & $\mathrm{Cu}$ & $\mathbf{F e}$ & Mn & & $\mathbf{Z n}$ & $\mathrm{Cu}$ & $\mathbf{F e}$ & Mn & $\mathbf{Z n}$ & $\mathrm{Cu}$ & $\mathbf{F e}$ & Mn \\
\hline T1(1:0) & 0.18 & 0.09 & 3.42 & 0.65 & 0.23 & 0.12 & 3.94 & 0.80 & T1(1:0:1) & 0.28 & 0.16 & 5.49 & 0.98 & 0.31 & 0.16 & 8.54 & 1.18 \\
\hline $\mathrm{T} 2(1: 1)$ & 0.35 & 0.16 & 6.02 & 1.13 & 0.43 & 0.19 & 7.94 & 1.38 & $\mathrm{~T} 2(1: 1: 1)$ & 0.42 & 0.23 & 8.32 & 1.25 & 0.43 & 0.26 & 10.65 & 1.74 \\
\hline T3(1:2) & 0.42 & 0.21 & 7.89 & 1.37 & 0.48 & 0.23 & 9.75 & 1.88 & T3(1:2:1) & 0.51 & 0.25 & 9.48 & 1.16 & 0.53 & 0.26 & 10.27 & 2.08 \\
\hline $\mathrm{T} 4(1: 3)$ & 0.54 & 0.26 & 10.73 & 1.96 & 0.60 & 0.31 & 11.42 & 2.35 & $\mathrm{~T} 4(1: 3: 1)$ & 0.68 & 0.32 & 12.88 & 2.36 & 0.61 & 0.33 & 11.97 & 2.46 \\
\hline $\mathrm{T} 5(0: 1)$ & 0.28 & 0.17 & 4.82 & 1.04 & 0.32 & 0.22 & 6.30 & 1.35 & T5(0:1:1) & 0.53 & 0.25 & 10.66 & 1.73 & 0.64 & 0.31 & 12.61 & 2.42 \\
\hline T6(2:1) & 0.27 & 0.15 & 5.06 & 1.08 & 0.35 & 0.20 & 6.85 & 1.35 & T6(2:1:1) & 0.51 & 0.26 & 9.84 & 1.58 & 0.63 & 0.28 & 11.84 & 2.38 \\
\hline $\mathrm{T} 7(3: 1)$ & 0.24 & 0.15 & 4.62 & 0.96 & 0.28 & 0.19 & 5.27 & 1.04 & T7(3:1:1) & 0.44 & 0.22 & 8.92 & 1.50 & 0.58 & 0.27 & 10.52 & 2.21 \\
\hline $\begin{array}{c}\mathrm{T} 8 \\
\text { (control1:1:1) }\end{array}$ & 0.10 & 0.36 & 1.88 & 0.47 & 0.11 & 0.05 & 1.89 & 0.43 & T8 C1(1:1:1) & 0.14 & 0.05 & 1.88 & 0.43 & 0.14 & 0.05 & 1.89 & 0.37 \\
\hline $\begin{array}{c}\text { T9 } \\
\text { (control1:1:1) }\end{array}$ & 0.20 & 0.63 & 4.12 & 0.79 & 0.20 & 0.36 & 4.13 & 0.78 & T9 C2(1:1:1) & 0.25 & 0.37 & 4.11 & 0.78 & 0.26 & 0.12 & 4.11 & 0.79 \\
\hline MEAN & 0.29 & 0.21 & 5.40 & 1.05 & 0.33 & 0.21 & 6.39 & 1.26 & MEAN & 0.42 & 0.23 & 7.95 & 0.95 & 0.46 & 0.23 & 9.16 & 1.74 \\
\hline SEm \pm & 0.005 & 0.09 & 0.034 & 0.004 & 0.005 & 0.039 & 0.017 & 0.005 & $\mathrm{SEm} \pm$ & 0.0048 & 0.089 & 0.040 & 0.011 & 0.0056 & 0.005 & 0.030 & 0.006 \\
\hline $\mathrm{CD}(\mathrm{P}=0.01)$ & 0.021 & 0.35 & 0.135 & 0.017 & 0.020 & 0.124 & 0.069 & 0.021 & $\begin{array}{c}\mathrm{CD}(\mathrm{P}= \\
0.01)\end{array}$ & 0.0192 & 0.354 & 0.161 & 0.045 & 0.0223 & 0.021 & 0.118 & 0.025 \\
\hline
\end{tabular}


The uptake of nitrogen varied from 23.91 to $97.17 \mathrm{mg}$ plant $^{-1}$ due to treatment effect of fly ash and farmyard manure in different proportions. Similar uptake pattern was also observed with pot mixture containing fly ash, vermicompost and soil. The most effective pot mixture treatment which influenced the uptake of nitrogen are 1:1 and 1:2 ratios with fly ash, farmyard manure and vermicompost pot mixture

Phosphorus uptake values ranged from 4.99 to $19.56 \mathrm{mg}$ plant $^{-1}$ in the pot mixture containing fly ash, FYM/VC in different proportions. However, the measured phosphorous uptake values differed marginally. In general, all the pot mixture containing FA, VC and FYM positively enhanced the uptake of phosphorus.

Similarly the uptake of potassium differed due to treatment effects. The pot mixture in $1: 1,1: 2$ and $1: 3$ ratio containing fly ash and farmyard manure or vermicompost had significantly influenced increased uptake of potassium compared to other treatment combinations.

\section{Micronutrients ( $\mathrm{Zn}, \mathrm{Cu}, \mathrm{Fe}, \mathrm{Mn}$ )}

The data presented in Table 4 indicates uptake of nutrient elements from pot mixture results in their differential bio accumulation influenced by many factors. The uptake of micronutrients by Simarouba gluca which varied as $\mathrm{Fe}>\mathrm{Mn}>\mathrm{Zn}>\mathrm{Cu}$ and corresponding nutrient concentration ranged from 1.88 to $10.73 \mathrm{mg} \mathrm{plant}^{-1}, 0.47$ to $1.96 \mathrm{mg} \mathrm{plant}^{-1}, 0.10$ to $0.54 \mathrm{mg}$ plant $^{-1}$ respectively in fly ash and FYM pot mixture. It was 1.89 to $11.42 \mathrm{mg}$ plant $^{-1}, 0.43$ to $2.35 \mathrm{mg} \mathrm{plant}^{-1}, 0.11$ to 0.60 $\mathrm{mg}$ plant $^{-1}$ and 0.05 to $0.31 \mathrm{mg}$ plant $^{-1}$ respectively in fly ash and VC pot mixture. Similar trend was also recorded due to pot mixture containing fly ash, farmyard manure or vermicompost with soil in different proportions.
Micronutrient uptake which varied as $\mathrm{Fe}>\mathrm{Mn}>\mathrm{Zn}>\mathrm{Cu}$ and corresponding nutrient concentration in pot mixture containing fly ash, farmyard manure, vermicompost and soil in different proportions were ranged from 1.88 to $12.88,0.43$ to $2.36,0.14$ to 0.68 and 0.05 to $0.37 \mathrm{mg} \mathrm{plant}^{-1}$ respectively.

The nutrient uptake in pot mixture containing fly ash, vermicompost and soil in different ratios ranged from 1.89 to 12.61 then 0.32 to 2.41 , then 0.14 to 0.64 and 0.005 to $0.33 \mathrm{mg}$ plant $^{-1}$ respectively.

The deferential bio accumulation of micronutrients by the forest species Populas deltoids and Cajurina was influenced by seasonal physiology and species was influenced by specific capacity for uptake forest species was recorded (Demidchick et $a l .$, 2000).

Increased biomass accumulation was observed in the pot mixture receiving fly ash, FYM and VC in $1: 2$ and 1:3 ratio (w/w). Further, it was improved in the pot mixture fly ash, FYM and VC and soil 1:2:1 and 1:3:1 ratio (w/w) in various plant parts of Simarouba gluca fly ash proportion in the potting mixture with organic substrates and soil accounted for up to 84 per cent over the control.

Fly ash incorporation FYM/VC and soil enrich the pot mixture with major and micro simultaneously led to a relative improvement of the stem and leaves.

A relative up take a greater up take of major and micronutrients was observed when pot mixture with soil as compared to without soil thus Simarouba gluca cultivation Simaroba seedling cultivation may be explored as an environmentally sound and cost effective technology for proper disposal and utilization of solid wastes. 


\section{References}

Agoramoorthy, G., Chen Fu-An. Hsu MJ, 2008. Threats of heavy metal pollution in halophytic and mangrove plants of Tamil Nadu, India. Environmental Pollution 155, 320-326.

Cavaleri, M. A., Gilmore, D. W., Mozaffari, M., Rosen, C. T. and Hallbach, T. R., 2004. Hybrid poplar and forest soil response to rnunicipal and industrial byproducts; a greenhouse study. $J$. Environ. Qual., 33(3): 1055-1061.

Demidchick, V., Davenport, R. J., Tester, I.
2000. Non-selective cation channels in plants. Ann. Rev. Pint. Rio.53:67-107.

Mountouris, A., Voutsas E, Tassios, D., 2002. Bioconcentrations of heavy metals in aquatic environments: the importance of bioavailability. Marine Pollution Bulletin. 44, 1136-1141.

Pryor, L. D., 1976. Biology of Eucalypts. Edward Arnold, London, pp 51-58.

Sharma, S. K., Kalra, N., 2006. Effect of fly ash incorporation on soil properties and productivity of crops: A review. Journal of Scientific and Industrial Research. $65,383-390$.

\section{How to cite this article:}

Rajashekhar, L., N.A. Yeledhalli and Patil, S.J. 2017. Effect of Fly Ash Based Organic Application on Plant Biomass and Bio Concentration of Major and Micro Nutrients in Nursery Seedlings of Simarouba gluca. Int.J.Curr.Microbiol.App.Sci. 6(10): 3366-3372. doi: https://doi.org/10.20546/ijcmas.2017.610.394 